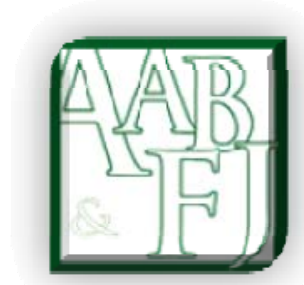

\title{
The Bank Lending Channel: Evidence from Australia
}

\author{
Xin Deng'ㄹ Luke Liu²
}

\begin{abstract}
This study explores how monetary policy changes flow through the banking sector in Australia. Drawing on data between 2004 and 2010, we divide banks into three groups according to their size, and examine the impact of that cash rate change on lending of different types of loans. We find the response of bank lending after a monetary policy change varies with the size of the bank as well as the types of loan. Smaller banks are more sensitive to policy rate changes, and household loans, government loans and intra-group loans are less responsive to monetary policy compared with financial and non-financial loans.
\end{abstract}

Keywords: monetary policy, transmission mechanism, lending channels, bank size, types of loans, Australia

JEL Code(s): E44, E52, G32.

\footnotetext{
1 School of Commerce, University of South Australia. Phone: 61-8-83020743. Email: xin.deng@unisa.edu.au

${ }^{2}$ Guanghua School of Management, Peking University, China; Minsheng Banking Corporate Limited, China. Email: liulvke@hotmail.com.
} 


\section{Introduction}

It is well documented that a monetary contraction is followed by a decline in aggregate bank lending (Bernanke \& Blinder 1992; Kashyap \& Stein 2000). However, the channel through which this policy is transmitted in different economies is unclear. Transmission channels identified in the literature are interest rate, bank lending, balance sheet and exchange rate channels (Becketti \& Morris 1992; Kakes \& Sturm 2002; Kashyap \& Stein 1995). The functioning of these channels is influenced by the economic, legal and financial structure in a specific country. Thus, differences in the structure of financial markets across countries would imply differences in transmission mechanisms. Therefore, a good understanding of the major transmission channels for a particular economy is essential to design a tailored monetary policy and to anticipate the impact of this policy. Given the crucial role of banks in facilitating the flow of funds, bank lending channel has received considerable attention among researchers and practitioners concerned with the transmission mechanism of monetary policy.

Australia's banking industry is dominated by four big banks: Commonwealth Bank, National Bank, Australia and New Zealand Bank (ANZ) and Westpac. The big four hold more than 90 percent of total loans. It has been argued that analysing panel data on banks' balance sheets is not of much value given the highly concentrated banking industry (Suzuki, 2004). However, given that the primary monetary policy decision of the Reserve Bank of Australia (RBA) has been to set the interest rate on overnight loans in the money market with the expectation that "the behaviour of borrowers and lenders in the financial markets is affected by monetary policy" (RBA 2011a), we cannot be sure that such an expectation is realistic unless we can produce the evidence of the changed behaviour and, more importantly, which group or which type of loans is more likely to change after a monetary policy shock.

Despite nearly two decades of policy implementation, there has been very little research on the monetary policy transmission mechanism in Australia. Suzuki (2004) is the only study of lending channels in Australia and he argues that loan contraction is largely due to a change in demand, thus lending channels are not dominant in Australia.

The disadvantage of aggregate data is the inability to identify whether there are differences in the way banks with different characteristics respond to policy shocks. It is difficult for policy makers to evaluate the impact of monetary policy without knowing how different groups of banks and different types of loans react to cash rate changes. Micro-data, on the other hand, will allow us to identify areas that are more sensitive to policy changes and to prepare for these changes. Studies performed in European countries with similar concentration levels in their banking industry support the existence of lending channel in some countries (Altunbas et al. 2002). Similar to European countries, Australia has a highly concentrated banking industry with the largest four banks accounting for more than 70 percent of asset value. Unlike countries within the Economic and Monetary Union (EMU) that have similar monetary policy but are under different legal and financial structures, Australia's economy operates under the same legal and financial structure and has the same monetary and fiscal policy. Therefore, it presents a good case to study bank lending channels in a small open developed economy.

The rest of the paper is organised as follows. Section 2 reviews the related literature, followed by data and the research methodology in Section 3. Section 4 presents the econometric results, and the paper concludes with a summary of the major findings and policy implications. 
Deng \& Liu | The Bank Lending Channel

\section{Literature Review}

Several studies have searched for empirical evidence of bank lending channels by employing aggregate data. An influential work by Bernanke and Blinder (1992) uses a vector auto regression (VAR) model to show that a contractionary monetary policy induces a decline in bank loans and economic activities. Many researchers have applied this methodology to different countries (Ashcraft 2006; Kakes \& Sturm 2002; Ramlogan 2004; Suzuki, 2004). However, their findings are inconsistent in terms of the role of the bank lending channel. For example, Kakes and Sturm (2002) analyse the impact of monetary shocks on bank lending in Germany and find that the response of bank lending after a monetary contraction varies considerably among banks of different sizes. The lending of the smallest banks declined most, whereas large banks were able to shield their loans' portfolio against monetary shocks. Overall, their results provide support for the existence of a bank lending channel. Ramlogan (2004) shows that the credit and exchange rate channels are more important than the interest rate channel in Caribbean countries. Buigut (2010) tests the lending channel using a vector error correction model in a framework that allows the identification of the shifts of demand and supply schedules in the bank loan market. The findings suggest the dominance of the bank lending channel in Kenya. In general, the majority of studies on asymmetries in the monetary transmission mechanism are based on macroeconomic evidence, which is abundant but often contradictory.

In practice, it is difficult to identify whether monetary policy directly affects loan supply or loan demand, as deposits are likely to contract when bank loans contract. One can then argue that a monetary tightening reduces aggregate demand for bank loans. A way to test this lending view is to examine the responses of banks to monetary policy using micro-data from the banks' balance sheets. Kashyap and Stein (1995) separate banks according to asset size and find that bank loan growth in the smallest asset category (below the $95^{\text {th }}$ percentile) is most responsive to monetary policy. Although they find support for the bank lending channel, they surmise that this test may not be stringent enough to separate loan supply effects from demand shocks. Kashyap and Stein (1997) further separate banks by asset size and liquidity and find that the smallest, most illiquid banks are most responsive to policy changes. Recent studies using European data reveal some interesting findings. Ehrmann et al. (2003) find that monetary policy does alter bank loan supply, with the effects most dependent on the liquidity of individual banks. Unlike in the United States, the size of a bank generally does not explain its lending reaction. Altunbas, Fazylov and Molyneux(2002) classify banks according to asset size and capital strength and find that across the EMU systems, undercapitalised banks (of any size) tend to respond more to changes in policy. Using a similar method, Matousek and Sarantis (2009) argue that bank size and liquidity play the most significant role in distinguishing banks' reactions to changes in monetary policy. Empirical studies on the relationship between monetary policy and loan growth outside the US have been dominated by cross-country studies due to data restrictions (Altunbas et al. 2002; Ashcraft 2006; Berger 2003). Studies on the US market found evidence of bank lending channels and that different sized banks have different sensitivities to monetary policy (Kishan \& Opiela 2000; Matousek \& Sarantis 2009).

In summary, existing research supports the existence of a bank lending channel and suggests that size and liquidity are factors that influence the magnitude of the policy response. However, in the absence of any examination of lending channels in Australia, a separate study for Australia is still necessary. In particular, we are interested in answering the following questions:

1. Is there evidence of bank lending channels in Australia?

2. Do different types of loans respond differently to monetary policy? 
3. Do banks of different sizes respond differently to monetary policy?

This paper takes a different perspective by using microeconomic data - the information contained in the balance sheets of individual banks - to study the sensitivity of banks in Australia to monetary policy. Thus, it extends the literature by specifying asset size along with different types of loans, to identify particular types of loans that are sensitive to monetary policy and to show further evidence of the existence of the bank lending channel in Australia.

\section{Data and Method}

As shown by Bernanke and Blinder (1992), macroeconomic time series are not helpful in identifying a lending channel that is actually the sub-channel of a credit channel. Aggregate data do not allow us to distinguish between supply and demand factors that affect banks' lending activities. Micro-data on banks, on the other hand, may effectively capture the distributional effects of monetary policy through a lending channel. Figure 1 shows the loan growth and the cash rate in Australia (2004:3-2010:12). The aggregate loan grew steadily during these years. We can clearly see that monetary policy has been contractionary except for the period between September 2008 and August 2010.

Figure 1

Loan Growth and the Cash Rate in Australia (2004:3-2010:12)

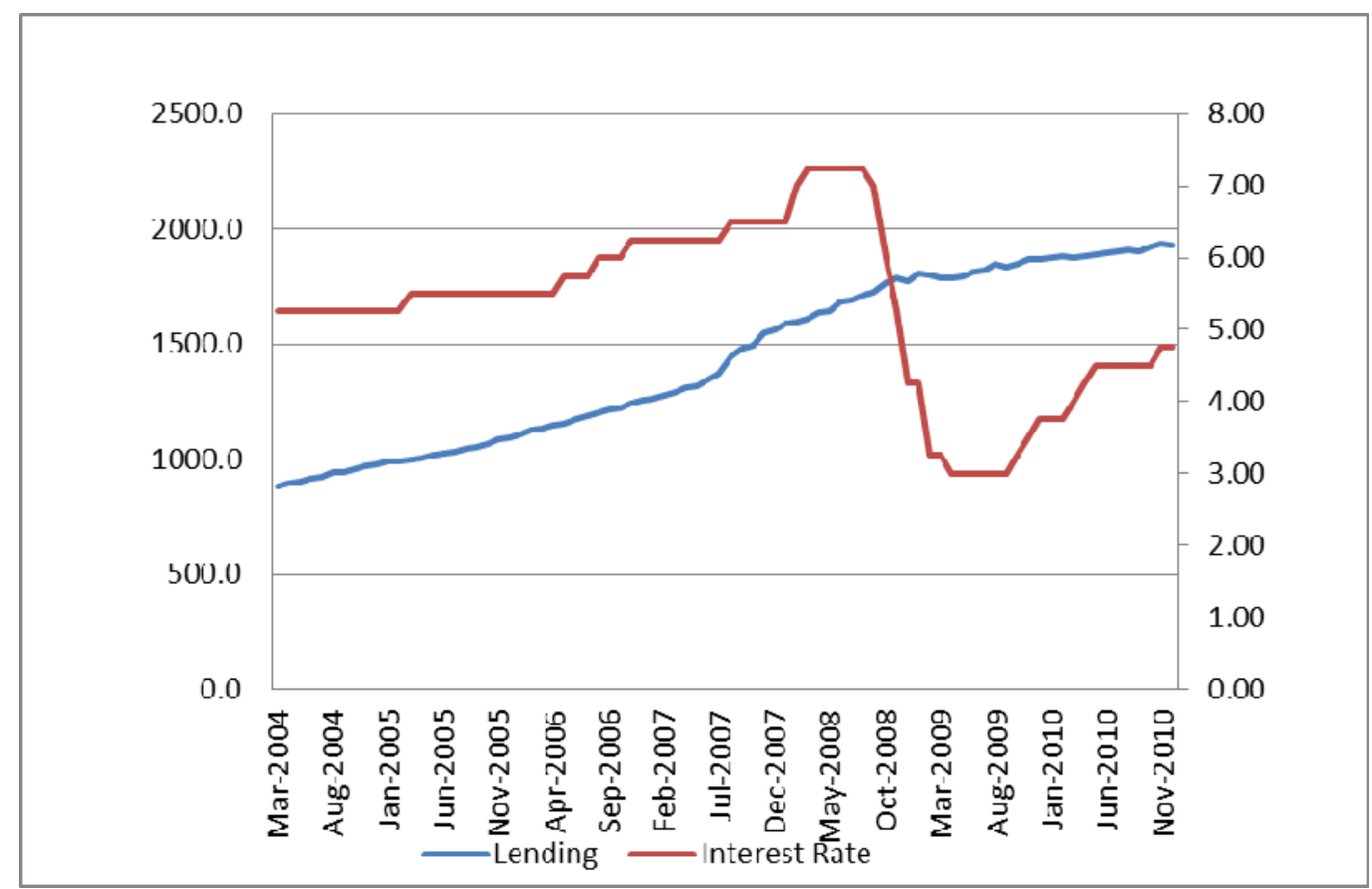

Lending: MillionA\$. Interest Rate: \%.

Source: The Australian Prudential Regulation Authority (APRA) 2011; RBA 2011b

Suppose that, as a result of monetary tightening, a bank's deposits decline. It can respond either by reducing its loans or by selling some of its securities holdings or liquid assets. Thus, liquidity and changes in deposits and holdings of securities affect bank lending. We therefore include liquidity and changes in deposits and holdings of securities in the econometric equation as control variables. However, research shows that liquidity and changes in deposits and holdings of securities can be influenced by the unobserved 
individual-level random effect, and thus should be considered as endogenous variables. To exclude the impact of the unobserved individual random effect, we choose the HausmanTaylor estimator for the error-components model as our econometric method and to control for individual-specific unobservable effects. ${ }^{3}$ In addition to the above balance-sheet items, we use a proxy for changes in monetary policy and a proxy for overall economic conditions. We use changes in cash rate as an indicator of monetary policy and the confidence index as an indicator for overall economic health.

The empirical model is presented in the following equation:

$\Delta \ln (\text { loans })_{i, t}=\beta_{0}$ srate $_{t}+\beta_{1} \Delta$ rate $_{t-1}+\beta_{2}$ srate $_{t-3}+\chi \Delta \ln \left(\right.$ Deposit $_{i, t}$

$+\gamma \Delta$ Confidence $+\delta \Delta \ln (\text { Securities })_{i, t}+\varepsilon \Delta$ liquidity $_{i, t}+\phi$ Nationality $_{i}+\partial_{i}+u_{i t}$

With $i=1, \ldots, \mathrm{N}$, and $t=1, \ldots, \mathrm{T}$, where $i$ refers to a bank and $t$ refers to a month.

We divide bank loans into five categories: loans to non-financial corporations, loans to financial corporations, loans to government, loans to households, and intra-group loans. We used the changes in cash rate one and three months previous to allow us to observe when the policy started to take effect. It is possible to include lagged values of two and four months, but this leads to the multicollinearity problem, and does not improve the model fit significantly, thus we only use one- and three-month lagged values. Westpac-Melbourne Institute consumer sentiment index published on RBA's website are used as confidence index (RBA 2011c). Change of logarithm of total deposits, change in liquidity and change in value of securities are also included as independent variables. The liquidity of a bank is measured as the ratio of liquid assets ${ }^{4}$ to the total assets and we also add a nationality dummy variable for domestic banks. $\partial_{i}$ is the individual-specific effects and $u_{i t}$ is the residuals.

Three tests are available to test model fit: likelihood ratio, Wald, and Lagrange multiplier (score) tests. When sample size is large enough, the outcome of the three tests are quite similar, and Wald test has the advantage that it only requires estimating one model (Agresti 2002). Given the relatively large sample size in this study, and the number of models to be tested, we use Wald test to find out whether the parameters associated with all explanatory variables are zero.

Table 1

Descriptive Statistics of the Bank Balance-sheet Data (2004:3-2010:12) (million \$A)

\begin{tabular}{l|l|l|l|l|l|l}
\hline \multicolumn{2}{c}{} & Mean & SD & Minimum & Maximum & Obs \\
\hline \multirow{2}{*}{$\begin{array}{l}\text { Total } \\
\text { resident } \\
\text { assets }\end{array}$} & Large & 269429.2 & 118617.8 & 66125.1 & 536016.8 & 400 \\
\cline { 2 - 7 } & Medium & 26582.9 & 16766.0 & 221.6 & 75694.5 & 1182 \\
\cline { 2 - 7 } & Small & 3636.8 & 3794.3 & 1.4 & 21085.3 & 2842 \\
\hline \multirow{2}{*}{$\begin{array}{l}\text { Gross } \\
\text { loans }\end{array}$} & Large & 184828.9 & 78567 & 50044 & 371483.4 & 400 \\
\cline { 2 - 7 } & Medium & 14207.6 & 13962.9 & 15 & 64362.5 & 1182 \\
\cline { 2 - 7 } $\begin{array}{l}\text { Loans } \\
\text { non- } \\
\text { financial }\end{array}$ & Small & 1895.3 & 2164.3 & .6 & 15371.2 & 2842 \\
\hline
\end{tabular}

3 The model fit panel-data random-effects model in which some of the covariates are correlated with the unobserved individual-level random effect. The estimators, originally proposed by Hausman and Taylor (1981) and Amemiya and MaCurdy (1986), are based on instrumental variables.

\footnotetext{
${ }^{4}$ There is a separate column of "Cash and liquid assets" in the APRA dataset, so we just used the data without further investigating the composition of liquid assets.
} 


\begin{tabular}{|c|c|c|c|c|c|c|}
\hline corporations & Small & 1430.5 & 1919.9 & .3 & 11023.5 & 2842 \\
\hline \multirow{3}{*}{$\begin{array}{l}\text { Loans to } \\
\text { financial } \\
\text { corporations }\end{array}$} & Large & 6194.9 & 4615.2 & 30.2 & 15791.3 & 400 \\
\hline & Medium & 493.7 & 743.6 & 0 & 6569.67 & 1182 \\
\hline & Small & 236.1 & 561.1 & 0 & 7829 & 2842 \\
\hline \multirow{3}{*}{$\begin{array}{l}\text { Loans to } \\
\text { households }\end{array}$} & Large & 130465.6 & 55113.7 & 42723.7 & 296232.8 & 400 \\
\hline & Medium & 8662.2 & 9905.7 & 0 & 41154.0 & 1181 \\
\hline & Small & 151.1 & 638.0 & 0 & 6123.3 & 2842 \\
\hline \multirow{3}{*}{$\begin{array}{l}\text { Loans to } \\
\text { government }\end{array}$} & Large & 1182.6 & 2370.2 & 3.5 & 11979.0 & 400 \\
\hline & Medium & 15.0 & 44.3 & 0 & 419.3 & 1182 \\
\hline & Small & .02 & .74 & 0 & 34.4 & 2842 \\
\hline \multirow{3}{*}{$\begin{array}{l}\text { Intra-group } \\
\text { Loans }\end{array}$} & Large & 7552.2 & 6550.6 & 1636.0 & 34950.5 & 400 \\
\hline & Medium & 3862.741 & 6667.171 & 0 & 40562.96 & 1182 \\
\hline & Small & 386.9315 & 1396.48 & 0 & 10660.2 & 2842 \\
\hline
\end{tabular}

Note: A resident is an individual, business or other organisation domiciled in Australia. Australian branches and Australian subsidiaries of foreign businesses are regarded as residents.

Source: APRA 2011; RBA 2011b

The cash rate data were collected from the RBA's website (http://www.rba.gov.au/statistics/tables/index.html). Data on the balance sheet items of commercial banks (for example, various types of loans, securities and deposits) were sourced from the Australian Prudential Regulation Authority's website (http://www.apra.gov.au/adi/Publications/Pages/monthly-banking-statistics.aspx) . The data are monthly from March 2004 to December 2010 for 61 commercial banks in Australia (15 Australian banks and 46 foreign banks). These 61 commercial banks account for $89.2 \%$ of the assets of the banking sector in Australia (APRA 2011).

We divided the 61 banks into three groups according to their assets value on December 31, 2010. Four large banks with a resident assets value of more than $\$ A 100,000$ million form Group 1 or large banks, Group 2, which contains 16 banks with a resident assets value of between $\$ A 10,000$ and 100,000 million, is labelled as medium banks. Group 3 includes 40 banks with a resident assets value of less than $\$ A 10,000$ million and is labelled as small banks. Banks with gross loans of 0 on December 31, 2010 are excluded from the sample. The statistics of the variables used are summarised in Table 1.

\section{Results}

The data were pooled by bank size, and a separate regression was run for each type of loan. In addition, a separate regression was run to test the impact of contractionary monetary policy. The results are presented in five sections: the impact of monetary policy on gross loans, loans to non-financial corporations, loans to financial corporations, loans to government, and loans to households and intra-group loans. Contractionary monetary policy is then discussed. Wald test results are significant at 1 percent level for all models expect for one (financial loans of large banks, which is significant at 5 percent level), indicating a good fit of the models.

\subsection{The Impact of Monetary Policy on Changes in Gross Loans}

Table 2 provides the econometric results of the model using gross loans as the dependent variable. From Table 2 we can see clearly that the impact of monetary policy on gross loans is most significant for banks in groups 2 and 3, or small and medium-sized banks. The sums of the coefficients associated with changes in cash rate are negative, statistically significant, and larger in absolute value for the banks with assets of less than \$A100,000 million, which shows that the small and medium-sized banks are more responsive to policy changes than are 
the large banks. This finding is consistent with research in the US (Berger \& Udell 1998; Kashyap \& Stein 1995). The results also show that cash rates lagged for one month have a negative impact on changes in gross loans for all groups while cash rates lagged for three months have no significant impact. A possible explanation is that smaller banks have few sources of funding, and limited access to cheap funding, so a change in the official cash rate will have a more significant impact on their funding by increasing their cost of funding compared with the larger banks. A contractionary monetary policy does not necessarily lead to more funding for smaller banks via high deposits due to their limited capacity to attract deposits. Consequently, their loan supply will be more responsive to monetary policy than will that of the larger banks. The scope of the lagged one-period effect is larger within the three groups, as indicated by the coefficients.

Table 2

The Effect of Monetary Policy on Changes in Gross Loans

\begin{tabular}{|c|c|c|c|}
\hline$\Delta \operatorname{Ln}($ Gross loans $)$ & Large & Medium & Small \\
\hline \multicolumn{4}{|l|}{ TV exogenous } \\
\hline$\Delta$ Cash rate & $\begin{array}{l}.1326253 \\
(0.180)\end{array}$ & $\begin{array}{l}.1320999^{* *} \\
(0.018)\end{array}$ & $\begin{array}{l}.1412393^{* * *} \\
(0.000)\end{array}$ \\
\hline L1. & $\begin{array}{l}-.2320546^{* *} \\
(0.050)\end{array}$ & $\begin{array}{l}-.2320075^{* * *} \\
(0.001)\end{array}$ & $\begin{array}{l}-.2398461^{* * *} \\
(0.000)\end{array}$ \\
\hline L3. & $\begin{array}{l}.0210143 \\
(0.842)\end{array}$ & $\begin{array}{l}.0176682 \\
(0.769)\end{array}$ & $\begin{array}{l}.0274472 \\
(0.477)\end{array}$ \\
\hline$\Delta$ Confidence & $\begin{array}{l}.0057412^{*} \\
(0.098)\end{array}$ & $\begin{array}{l}.0059369^{* * *} \\
(0.003)\end{array}$ & $\begin{array}{l}.005918^{* * *} \\
(0.000)\end{array}$ \\
\hline \multicolumn{4}{|l|}{ TV endogenous } \\
\hline$\Delta \operatorname{Ln}($ Total deposits $)$ & $\begin{array}{l}.2126814^{* * *} \\
(0.001)\end{array}$ & $\begin{array}{l}.202142^{* * *} \\
(0.000)\end{array}$ & $\begin{array}{l}.2191146^{* * *} \\
(0.000)\end{array}$ \\
\hline$\Delta$ Liquidity & $\begin{array}{l}.2089094 \\
(0.575)\end{array}$ & $\begin{array}{l}.1991415 \\
(0.349)\end{array}$ & $\begin{array}{l}.2103143 \\
(0.138)\end{array}$ \\
\hline$\Delta \operatorname{Ln}($ Securities $)$ & $\begin{array}{l}.2030038^{* * *} \\
(0.000)\end{array}$ & $\begin{array}{l}.2014548^{* * *} \\
(0.000)\end{array}$ & $\begin{array}{l}.2258066^{* * *} \\
(0.000)\end{array}$ \\
\hline \multicolumn{4}{|l|}{ TI exogenous } \\
\hline Nationality & $\begin{array}{l}-.0001035 \\
(0.998)\end{array}$ & $\begin{array}{l}-.0085087 \\
(0.722)\end{array}$ & $\begin{array}{l}-.0045696 \\
(0.853)\end{array}$ \\
\hline No. of obs & 385 & 1134 & 2272 \\
\hline Wald Test & $\begin{array}{l}67.86^{* * *} \\
(0.000)\end{array}$ & $\begin{array}{l}199.06^{* * *} \\
(0.000)\end{array}$ & $\begin{array}{l}531.82^{* * *} \\
(0.000)\end{array}$ \\
\hline
\end{tabular}

Changes in deposits and security holdings have a significant impact on changes in gross loans for all groups, which seems to confirm the existence of the lending channel. That 
is, a contractionary monetary policy that decreases bank deposits and security holdings will reduce the amount of funds available for banks to lend to their borrowers and hence reduce gross loans.

Surprisingly, liquidity has no impact on banks' lending behaviour. This is different from findings in the US and European countries (e.g. Ehrmann et al. 2001; Kashyap \& Stein 2000). It is interesting to see whether the pattern remains the same for the subgroups of loans.

\subsection{The Effect of Monetary Policy on Changes in Non-Financial Loans}

At the end of 2009, small and medium-sized banks jointly accounted for 12 percent of total non-financial loans, with the rest issued by the big banks.

As illustrated in Table 3, changes in non-financial loans are negatively linked with the cash rate changes in the current period as well as three months ago for all groups, although the link is stronger for small and medium banks. The change in confidence level has a significant positive impact on changes in non-financial loans, suggesting that this type of loan is heavily affected by economic conditions.

Table 3

The Effect of Monetary Policy on Changes in Non-Financial Loans

\begin{tabular}{|c|c|c|c|}
\hline$\Delta \operatorname{Ln}($ Non-financial loans) & Large & Medium & Small \\
\hline \multicolumn{4}{|l|}{ TV exogenous } \\
\hline$\Delta$ Cash rate & $\begin{array}{l}-.185068^{* *} \\
(0.043)\end{array}$ & $\begin{array}{l}-.1885477^{* *} \\
(0.000)\end{array}$ & $\begin{array}{l}-.1769455^{* * *} \\
(0.000)\end{array}$ \\
\hline L1. & $\begin{array}{l}-.0153639 \\
(0.888)\end{array}$ & $\begin{array}{l}.0009321 \\
(0.988)\end{array}$ & $\begin{array}{l}-.0162217 \\
(0.686)\end{array}$ \\
\hline L3. & $\begin{array}{l}-.1712364^{*} \\
(0.079)\end{array}$ & $\begin{array}{l}-.1719267^{* *} \\
(0.002)\end{array}$ & $\begin{array}{l}-.1705182^{* * *} \\
(0.000)\end{array}$ \\
\hline$\Delta$ Confidence & $\begin{array}{l}.0118983^{* * *} \\
(0.000)\end{array}$ & $\begin{array}{l}.0122596^{* * *} \\
(0.000)\end{array}$ & $\begin{array}{l}.0120309^{* * *} \\
(0.000)\end{array}$ \\
\hline \multicolumn{4}{|l|}{ TV endogenous } \\
\hline$\Delta \operatorname{Ln}($ Total deposits $)$ & $\begin{array}{l}.0640309 \\
(0.292)\end{array}$ & $\begin{array}{l}.080041^{* * *} \\
(0.021)\end{array}$ & $\begin{array}{l}.0623335^{* * *} \\
(0.006)\end{array}$ \\
\hline$\Delta$ Liquidity & $\begin{array}{l}-.0837326 \\
(0.808)\end{array}$ & $\begin{array}{l}-.1037231 \\
(0.599)\end{array}$ & $\begin{array}{l}-.0828052 \\
(0.529)\end{array}$ \\
\hline$\Delta \operatorname{Ln}($ Securities $)$ & $\begin{array}{l}.281488^{* * *} \\
(0.000)\end{array}$ & $\begin{array}{l}.2769269^{* * *} \\
(0.000)\end{array}$ & $\begin{array}{l}.2933415^{* * *} \\
(0.000)\end{array}$ \\
\hline \multicolumn{4}{|l|}{ TI exogenous } \\
\hline Nationality & $\begin{array}{l}-.003394 \\
(0.931)\end{array}$ & $\begin{array}{l}-.0044687 \\
(0.840)\end{array}$ & $\begin{array}{l}-.0040756 \\
(0.859)\end{array}$ \\
\hline No. of obs & 385 & 1134 & 2272 \\
\hline Wald Test & $\begin{array}{l}124.81^{* * *} \\
(0.000)\end{array}$ & $\begin{array}{l}368.24^{* * *} \\
(0.000)\end{array}$ & $\begin{array}{l}968.54^{* * *} \\
(0.000)\end{array}$ \\
\hline
\end{tabular}


While security holdings continue to affect changes in non-financial loans, changes in deposits have little influence on loans issued by large banks. Given the dominant position of large banks, it may be argued that the lending channel is less evident in non-financial loans. The lack of connection between deposits and lending among large institutions for nonfinancial loans may be explained by their nature. The borrowers of those loans are predominantly companies whose profitability depends on economic conditions, thus, they are more likely to be affected by the overall economy instead of change of deposits. Indeed, we can observe a strong link between confidence levels and non-financial loans across all groups.

\subsection{The Effect of Monetary Policy on Changes in Financial Loans}

Similar to non-financial loans, large banks control 90 percent of the market, and small and medium-sized banks share the rest.

We can see from Table 4 that cash rate changes have a significant impact only on the financial loans of the small and medium-sized banks. However, liquidity plays an important role in this type of loan. It has a significant positive impact on the financial loans of all banks, with the relationship being more significant among banks in small and medium-sized groups. Deposit and security holdings remain significant but less important factors for financial loans. The results suggest that financial loans issued by large banks are not sensitive to either cash rate changes or changes in deposits, but are subject to liquidity constraint. Changes in securities, on the other hand, have a consistently significant impact on changes in financial loans across the three groups, which implies a strong link between security and financial loans. Liquidity also has a significant effect on financial loan growth within the three groups. Changes in deposits may be more important for small and medium-sized groups.

\section{Table 4}

The Effect of Monetary Policy on Changes in Financial Loans

\begin{tabular}{|c|c|c|c|}
\hline$\Delta \operatorname{Ln}($ Financial loans $)$ & Large & Medium & Small \\
\hline \multicolumn{4}{|l|}{ TV exogenous } \\
\hline$\Delta$ Cash rate & $\begin{array}{l}.3328578 \\
(0.122)\end{array}$ & $\begin{array}{l}.3295236^{* * *} \\
(0.007)\end{array}$ & $\begin{array}{l}.3460091^{* * *} \\
(0.000)\end{array}$ \\
\hline L1. & $\begin{array}{l}-.5703139 \\
(0.026)\end{array}$ & $\begin{array}{l}-.5758824^{* * *} \\
(0.000)\end{array}$ & $\begin{array}{l}-.5784877^{* * *} \\
(0.000)\end{array}$ \\
\hline L3. & $\begin{array}{l}.221212 \\
(0.96)\end{array}$ & $\begin{array}{l}.2378541^{* *} \\
(0.073)\end{array}$ & $\begin{array}{l}.222943^{* * *} \\
(0.007)\end{array}$ \\
\hline$\Delta$ Confidence & $\begin{array}{l}.0067025 \\
(0.374)\end{array}$ & $\begin{array}{l}.0066106 \\
(0.130)\end{array}$ & $\begin{array}{l}.0057959^{* *} \\
(0.040)\end{array}$ \\
\hline \multicolumn{4}{|l|}{ TV endogenous } \\
\hline$\Delta \operatorname{Ln}$ (Total deposits) & $\begin{array}{l}.1882708 \\
(0.187)\end{array}$ & $\begin{array}{l}.1812147^{* *} \\
(0.028)\end{array}$ & $\begin{array}{l}.1823482^{* * *} \\
(0.001)\end{array}$ \\
\hline$\Delta$ Liquidity & $\begin{array}{l}1.830437^{* *} \\
(0.024)\end{array}$ & $\begin{array}{l}1.84819^{* * *} \\
(0.000)\end{array}$ & $\begin{array}{l}1.801847^{* * *} \\
(0.000)\end{array}$ \\
\hline$\Delta \operatorname{Ln}($ Securities $)$ & $\begin{array}{l}.1510513^{* *} \\
(0.021)\end{array}$ & $\begin{array}{l}.1492991^{* * *} \\
(0.000)\end{array}$ & $\begin{array}{l}.1503628^{* * *} \\
(0.000)\end{array}$ \\
\hline \multicolumn{4}{|l|}{ TI exogenous } \\
\hline Nationality & $\begin{array}{l}.0001091 \\
(0.999)\end{array}$ & $\begin{array}{l}.0017764 \\
(0.973)\end{array}$ & $\begin{array}{l}-.0038054 \\
(0.943)\end{array}$ \\
\hline No. of obs & 385 & 1134 & 2272 \\
\hline Wald Test & $\begin{array}{l}16.48^{* *} \\
(0.0360)\end{array}$ & $\begin{array}{l}48.63^{* * *} \\
(0.000)\end{array}$ & $\begin{array}{l}121.97^{* * *} \\
(0.000)\end{array}$ \\
\hline
\end{tabular}


Note: 1. TV refers to time varying; TI refers to time invariant.

2. P-values in parentheses.

$*=$ Significant at $10 \%$ confidence level. $* *=$ Significant at $5 \%$ confidence level. $* * *=$ Significant at $1 \%$ confidence level

\subsection{The Effect of Monetary Policy on Changes in Household Loans}

In the household loan market, the large banks have the largest market share, with the small banks having about 0.2 percent and the medium-sized banks 5.8 percent of market share, respectively.

Table 5

The Effect of Monetary Policy on Changes in Household Loans

\begin{tabular}{|c|c|c|c|}
\hline$\Delta \operatorname{Ln}($ Household loans) & Large & Medium & Small \\
\hline \multicolumn{4}{|l|}{ TV exogenous } \\
\hline$\Delta$ Cash rate & $\begin{array}{l}-.1006575 \\
(0.650)\end{array}$ & $\begin{array}{l}-.0817947 \\
(0.481)\end{array}$ & $\begin{array}{c}-.0932167 \\
(0.258)\end{array}$ \\
\hline L1. & $\begin{array}{l}-.2878169 \\
(0.278)\end{array}$ & $\begin{array}{l}-.2284416 \\
(0.101)\end{array}$ & $\begin{array}{l}-.2758241 * * * \\
(0.005)\end{array}$ \\
\hline L3. & $\begin{array}{l}.4510989 * \\
(0.057)\end{array}$ & $\begin{array}{l}.3720929 * * * \\
(0.003)\end{array}$ & $\begin{array}{l}.4612669 * * * \\
(0.000)\end{array}$ \\
\hline$\Delta$ Confidence & $\begin{array}{l}.0030403 \\
(0.696)\end{array}$ & $\begin{array}{l}.0026412 \\
(0.522)\end{array}$ & $\begin{array}{l}.0034277 \\
(0.254)\end{array}$ \\
\hline \multicolumn{4}{|l|}{ TV endogenous } \\
\hline$\Delta \operatorname{Ln}$ (Total deposits) & $\begin{array}{l}.8827474 * * * \\
(0.000)\end{array}$ & $\begin{array}{l}.7242075^{* * *} \\
(0.000)\end{array}$ & $\begin{array}{l}.9244411 * * * \\
(0.000)\end{array}$ \\
\hline$\Delta$ Liquidity & $\begin{array}{c}.175362 \\
(0.834)\end{array}$ & $\begin{array}{l}.165428 \\
(0.708)\end{array}$ & $\begin{array}{l}.2231911 \\
(0.491)\end{array}$ \\
\hline$\Delta \operatorname{Ln}($ Securities $)$ & $\begin{array}{l}-.0402598 \\
(0.550)\end{array}$ & $\begin{array}{l}-.0301845 \\
(0.403)\end{array}$ & $\begin{array}{l}-.0449075^{*} \\
(0.076)\end{array}$ \\
\hline \multicolumn{4}{|l|}{ TI exogenous } \\
\hline Nationality & $\begin{array}{l}.0072881 \\
(0.939)\end{array}$ & $\begin{array}{l}-.0419768 \\
(0.399)\end{array}$ & $\begin{array}{l}-.0044369 \\
(0.937)\end{array}$ \\
\hline No. of obs & 385 & 1134 & 2272 \\
\hline Wald Test & $\begin{array}{l}46.05 * * * \\
(0.0120)\end{array}$ & $\begin{array}{l}111.29 * * * \\
(0.000)\end{array}$ & $\begin{array}{l}346.10^{* * * *} \\
(0.000)\end{array}$ \\
\hline
\end{tabular}

Note: 1. TV refers to time varying; TI refers to time invariant.

2. P-values in parentheses.

$*=$ Significant at $10 \%$ confidence level. $* *=$ Significant at $5 \%$ confidence level. $* * *=$ Significant at $1 \%$ confidence level.

Table 5 provides estimates of the effect of policy on changes in household loans. Household loans across all three groups are insensitive to the current change in cash rates. Since household loans are often collateralised and have a long maturity, they cannot be readily adjusted relative to other types of loan. Thus, household loans are less responsive to monetary policy than are the other types of loans, which defies common sense. The one- 
period lagged cash rate change has a negative effect on household loan growth while the lagged three-period cash rate changes have a positive effect.

An interesting issue to note here is that changes in securities have a negative effect on changes in household loans. The effect of changes in deposits and securities has a very significant explanatory power in all cases. The liquidity rate has no significant effect on household loans for the three groups.

\subsection{The Effect of Monetary Policy on Changes in Government Loans and Intra-Group Loans}

The distribution of government and intra-group loans provides an interesting contrast. While large banks issue 99 percent of total government loans, their share of intra-group loans is less than two-thirds, suggesting that intra-group loans are an important funding mechanism for small and medium-sized banks.

From Table 6 we can see that the factors that influence government loans are quite different from those for other types of loan. First, loans issued by large banks are not affected by changes in cash rates or confidence levels. Second, while changes in security holdings are a significant factor for all other types of loans, they have little impact on government loans. Liquidity, on the other hand, seems to play an important role in this regard. Changes in government loans are negatively associated with changes in deposits. In other words, an increase in deposits tends to reduce loans to government. A possible explanation for this negative relationship is that banks may issue more government loans when the economy is not performing well. Overall, loans to government seem to complement other types of loans and to depend heavily on bank liquidity.

Table 6

The Effect of Monetary Policy on Changes in Government Loans

\begin{tabular}{llll}
\hline $\begin{array}{l}\Delta \text { Ln(Government } \\
\text { loans) }\end{array}$ & Large & Medium & Small \\
\hline TV exogenous & & & \\
$\Delta$ Cash rate & .0330169 & .0326211 & $.0346448^{*}$ \\
& $(0.531)$ & $(0.285)$ & $(0.093)$ \\
L1. & -.086053 & $-.0835685^{* *}$ & $-.0933477^{* * *}$ \\
& $(0.172)$ & $(0.022)$ & $(0.000)$ \\
L3. & -.0517623 & -.0429927 & $-.049594^{* * *}$ \\
& $(0.357)$ & $(0.191)$ & $(0.024)$ \\
$\Delta$ Confidence & .001769 & $.0020297^{*}$ & $.0023289^{* * *}$ \\
& $(0.338)$ & $(0.061)$ & $(0.002)$ \\
\hline TV endogenous & & & \\
$\Delta$ Ln(Total deposits) & $-.1235304^{* * *}$ & $-.1086009^{* * *}$ & $-.1273584^{* * *}$ \\
$\Delta$ Liquidity & $(0.000)$ & $(0.000)$ & $(0.000)$ \\
& $.2414917^{* * *}$ & $.2660619^{* * *}$ & $.3099602^{* * *}$ \\
$\Delta$ Ln(Securities) & $(0.224)$ & $(0.022)$ & $(0.000)$ \\
\hline TI exogenous & .0021544 & .0004288 & .0020581 \\
Nationality & $(0.893)$ & $(0.964)$ & $(0.745)$ \\
\hline No. of obs & & & \\
Wald Test & .0051246 & .0093967 & .0062112 \\
\hline
\end{tabular}




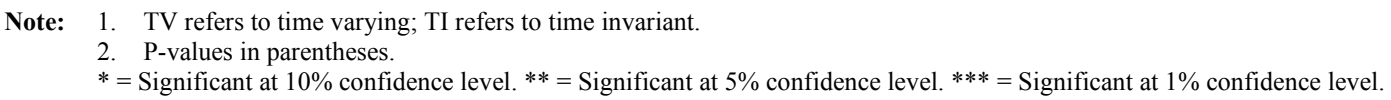

Government loans issued by banks in the small and medium-sized groups are sensitive to the cash rate change in the previous month, and are sensitive to changes in confidence levels. However, since the large banks issue more than 99 percent of government loans, we may conclude that liquidity is the single most important factor to influence this type of loan, and government loans may be more attractive when the economy is not performing well.

Table 7

The Effect of Monetary Policy on Changes in Intra-Group Loans

\begin{tabular}{|c|c|c|c|}
\hline$\Delta \mathrm{Ln}$ (Intra-group loans) & Large & Medium & Small \\
\hline \multicolumn{4}{|l|}{ TV exogenous } \\
\hline$\Delta$ Cash rate & $\begin{array}{l}.0840316 \\
(0.405)\end{array}$ & $\begin{array}{l}.0845311 \\
(0.132)\end{array}$ & $\begin{array}{l}.0865724^{* *} \\
(0.023)\end{array}$ \\
\hline L1 & $\begin{array}{l}.0061226 \\
(0.960)\end{array}$ & $\begin{array}{l}.0118461 \\
(0.860)\end{array}$ & $\begin{array}{l}-.0071046 \\
(0.876)\end{array}$ \\
\hline L3 & $\begin{array}{l}-.1500607 \\
(0.163)\end{array}$ & $\begin{array}{l}-.1272457^{* *} \\
(0.035)\end{array}$ & $\begin{array}{l}-.1417768^{* * *} \\
(0.000)\end{array}$ \\
\hline$\Delta$ Confidence & $\begin{array}{c}.004108 \\
(0.246)\end{array}$ & $\begin{array}{l}.0048333^{* *} \\
(0.015)\end{array}$ & $\begin{array}{l}.0048743^{* * *} \\
(0.000)\end{array}$ \\
\hline \multicolumn{4}{|l|}{ TV endogenous } \\
\hline$\Delta \mathrm{Ln}($ Total deposits $)$ & $\begin{array}{l}-.2639747^{* * *} \\
(0.000)\end{array}$ & $\begin{array}{l}-.225146^{* * *} \\
(0.000)\end{array}$ & $\begin{array}{l}-.2751279^{* * *} \\
(0.000)\end{array}$ \\
\hline$\Delta$ Liquidity & $\begin{array}{l}-1.045906^{* * *} \\
(0.000)\end{array}$ & $\begin{array}{l}-1.025066^{* * *} \\
(0.000)\end{array}$ & $\begin{array}{l}-1.033774^{* * *} \\
(0.000)\end{array}$ \\
\hline$\Delta \mathrm{Ln}($ Securities $)$ & $\begin{array}{l}-.1343265^{* * *} \\
(0.000)\end{array}$ & $\begin{array}{l}-.1378571^{* * *} \\
(0.000)\end{array}$ & $\begin{array}{l}-.1316015^{* * *} \\
(0.000)\end{array}$ \\
\hline \multicolumn{4}{|l|}{ TI exogenous } \\
\hline Nationality & $\begin{array}{l}-.005263 \\
(0.903) \\
\end{array}$ & $\begin{array}{l}.0102569 \\
(0.669) \\
\end{array}$ & $\begin{array}{l}.0008866 \\
(0.973) \\
\end{array}$ \\
\hline No. of obs & 385 & 1134 & 2272 \\
\hline Wald Test & $\begin{array}{l}52.65^{* * *} \\
(0.0000)\end{array}$ & $\begin{array}{l}151.67^{* * *} \\
(0.000)\end{array}$ & $\begin{array}{l}362.66^{* * *} \\
(0.000)\end{array}$ \\
\hline
\end{tabular}

Intra-group loans also display unique patterns in terms of factors. Similar to government loans, large banks are not sensitive to changes in cash rates or confidence levels. Liquidity again plays an important role, and changes in deposits and security holdings are negatively related to changes in intra-group loans. This negative relationship is not difficult to understand considering that the major purpose of intra-group loans is to provide extra funding for member banks that face liquidity issues and are unable to obtain enough funds from deposits and other sources. 


\subsection{The Impact of Contractionary Monetary Policy}

This section provides estimates of the impact of contractionary monetary policy on different types of loans. Change in the cash rate in the current period was excluded in the model to address the multicollinearity issue. Overall, we observe the correlation between change of the cash rate and lending across all types of loans. Cash rate changes in both the one- and threemonth lagged periods have significant negative effects on loan growth apart from nonfinancial loans where only the cash rate change of one lagged period is significant. Changes in confidence levels also have a significant impact on all types of loan. Compared to the results showing that the impact of the confidence level is only evident for certain types of loan, this may imply that sentiment plays a more important role in a contractionary policy environment. The magnitude of the impact also varies among different types of loans. Nonfinancial loans are the most sensitive. A one percent increase in the lagged one-period monetary policy rate leads to more than 1.1 percent decline in the log of changes in nonfinancial loans while the same policy shock leads to less than 0.5 percent decline in the log of changes in household loans. 
Table 8

Impact of a Cash Rate Hike

$\Delta$ Cash rate $>0$

Gross loans _ Non-financial loans _ Financial loans

Household loans

Government loans

Intra-group loans

\section{$\Delta$ Cash rate}

\begin{tabular}{|c|c|c|c|c|c|c|}
\hline L1. & $\begin{array}{l}-1.301463^{* * *} \\
(0.000)\end{array}$ & $\begin{array}{l}-1.132996^{* * *} \\
(0.000)\end{array}$ & $\begin{array}{l}-.9632873^{* * *} \\
(0.001)\end{array}$ & $\begin{array}{l}-.1228664^{* * *} \\
(0.000)\end{array}$ & $\begin{array}{l}-.1060478^{* * *} \\
(0.000)\end{array}$ & $\begin{array}{l}-1.037662^{* * *} \\
(0.000)\end{array}$ \\
\hline L3. & $\begin{array}{l}-1.539959^{* * *} \\
(0.000)\end{array}$ & $\begin{array}{l}-2.076279^{* * *} \\
(0.000)\end{array}$ & $\begin{array}{r}3.53035 \\
(0.512)\end{array}$ & $\begin{array}{l}-.0627532^{* * *} \\
(0.000)\end{array}$ & $\begin{array}{l}-.0600187^{* * *} \\
(0.000)\end{array}$ & $\begin{array}{l}-.5473752^{* * *} \\
(0.000)\end{array}$ \\
\hline$\Delta$ Confidence & $\begin{array}{l}.0121635^{* * *} \\
(0.000)\end{array}$ & $\begin{array}{l}.0068861^{* * *} \\
(0.000)\end{array}$ & $\begin{array}{l}.0450123^{* * *} \\
(0.000)\end{array}$ & $\begin{array}{l}.0018181^{* * *} \\
(0.000)\end{array}$ & $\begin{array}{l}.0021186^{* * *} \\
(0.000)\end{array}$ & $\begin{array}{l}.0254334^{* * *} \\
(0.000)\end{array}$ \\
\hline$\Delta \operatorname{Ln}$ (Total deposits) & $\begin{array}{l}-.1211497^{* *} \\
(0.015)\end{array}$ & $\begin{array}{l}-.0303632 \\
(0.514)\end{array}$ & $\begin{array}{l}-1.421162^{* * *} \\
(0.000)\end{array}$ & $\begin{array}{l}-.0117843^{* *} \\
(0.013)\end{array}$ & $\begin{array}{l}-.0293342^{* * *} \\
(0.000)\end{array}$ & $\begin{array}{l}.1403724^{* * *} \\
(0.089)\end{array}$ \\
\hline$\Delta$ Liquidity rate & $\begin{array}{l}-2.657872^{* * *} \\
(0.000)\end{array}$ & $\begin{array}{l}-3.408447^{* * *} \\
(0.000)\end{array}$ & $\begin{array}{c}2.21163^{*} \\
(0.059)\end{array}$ & $\begin{array}{l}.0480198^{* * *} \\
(0.002)\end{array}$ & $\begin{array}{l}-.0288224^{* * *} \\
(0.000)\end{array}$ & $\begin{array}{l}.6287878^{* *} \\
(0.022)\end{array}$ \\
\hline$\Delta \mathbf{L n}$ (Securities) & $\begin{array}{l}.5022572^{* * *} \\
(0.000)\end{array}$ & $\begin{array}{l}.6746423^{* * *} \\
(0.000)\end{array}$ & $\begin{array}{l}.2309256^{* * *} \\
(0.000)\end{array}$ & $\begin{array}{l}-.0063806 \\
(0.000)\end{array}$ & $\begin{array}{l}-.0080263^{* * *} \\
(0.000)\end{array}$ & $\begin{array}{l}-.3248476^{* * *} \\
(0.000)\end{array}$ \\
\hline Nationality & $\begin{array}{l}.0000672 \\
(0.816)\end{array}$ & $\begin{array}{l}-.0032833 \\
(0.854)\end{array}$ & $\begin{array}{l}.0047947 \\
(0.755)\end{array}$ & $\begin{array}{l}.0009984 \\
(0.584)\end{array}$ & $\begin{array}{l}-.000863 \\
(0.201)\end{array}$ & $\begin{array}{l}.0124213 \\
(0.695)\end{array}$ \\
\hline No. of obs & 807 & & & & & \\
\hline Wald Test & $\begin{array}{l}4803.18^{* * *} \\
(0.000)\end{array}$ & $\begin{array}{l}9162.63^{* * *} \\
(0.000)\end{array}$ & $\begin{array}{l}622.49^{* * *} \\
(0.000)\end{array}$ & $\begin{array}{l}244.70^{* * *} \\
(0.000)\end{array}$ & $\begin{array}{l}1493.08^{* * *} \\
(0.000)\end{array}$ & $\begin{array}{l}427.68^{* * *} \\
(0.000)\end{array}$ \\
\hline
\end{tabular}


Deng \& Liu | The Bank Lending Channel

\section{Conclusions}

Previous studies suggest that the transmission mechanism of monetary policy is related to the economic, legal and financial structure of a specific country. Thus, country studies are important to understand the impact of monetary policy. This paper uses microdata from individual bank balance sheets to study monetary policy on bank lending in Australia and reveals some interesting findings.

First, this study confirms the existence of lending channels in Australia, which answers our first research question. A significant negative relationship between a change in the cash rate in the previous month and changes in loans has been identified for gross loans and non-financial loans for all groups. Other types of loans issued by large banks are not sensitive to cash rate changes, but overall we observe a significant negative relationship between changes in loans and cash rate hikes, suggesting the lending channels are effective at least for contractionary policy.

Second, smaller banks are more sensitive to changes in the cash rate. Negative correlation at the 1 percent significance level between lending and rate changes has been detected for all types of loans issued by small banks. Correlation at the same significance level has been found among medium-sized banks for gross loans and financial loans, but the significance level drops to 5 percent for non-financial, government and intra-group loans. While the gross lending from the big banks is negatively related to the cash rate change in the previous month, it seems that such correlation is mainly driven by the changes in nonfinancial loans as no statistically significant correlation has been identified for other types of loan.

Third, the strong link between deposits and lending for small and medium banks across all types of loans suggests deposits remain a crucial funding source for the bank lending, and access to deposits may explain smaller banks' sensitivity to cash rate change to some extent. This link can also support the Australian government's introduction of deposit insurance for Australian banks during the Global Financial Crisis. This study suggests that large scale of deposit withdrawal will significantly impact on the bank lending, especially on household loans and smaller and medium banks. Without deposit insurance, smaller banks are likely to be severely affected by withdrawals and could end up with bankruptcy. Given the large number of small banks, even a small proportion of troubled banks could have a disastrous effect on market confidence, raising concerns about financial institutions' viability and causing panic reactions in the financial market.

Contrary to previous studies, we are unable to confirm the link between liquidity and changes in bank lending. The relationship between changes in liquidity and loans is not significant except for financial, government and intra-group loans. The correlation is positive for the first two types, and negative for intra-group loans. It is surprising to observe the negative correlation between liquidity and intra-group loans, which seems to suggest that the more liquid a bank is, the less likely it is to lend to another bank. While a significant link between liquidity and loan type has been detected in a contractionary policy environment, the direction of the impact varies among different loans. It is positively related to financial loans, household and intra-group loans, but negatively related to other types of loans. While it is possible to argue that liquidity plays different roles in different types of loans, further study is needed to provide more convincing evidence.

Last, this study reveals that the impact of monetary policy varies with banks of different size and with different kinds of loans. Household loans seem to be the least sensitive to rate changes as lending from large and medium banks is not significantly correlated with cash rate changes. Non-financial loans, on the other hand, seem to be the most sensitive type, with the lending of all three groups significantly related to the rate changes. As well, the reaction time varies with different types of loans. The majority of loans are sensitive to the 
rate change in the previous month, but non-financial loans are sensitive to rate changes in both the current month and three months ago, and intra-group loans are sensitive to the rate change three months ago. The different sensitivity of loans may be explained from both the supply and the demand side. From the demand side, it implies that the demand elasticity for different types of loans may be different. Household loans, for example, may not be adjusted as easily as loans to firms. From the supply side, the risk profile of the various loans is quite different, which may affect a bank's willingness to lend. A change in the confidence index has a strong impact on non-financial loans across all groups, but has little impact on household and financial loans. This suggests that non-financial loans are the most likely to be affected by any change of economic conditions.

In summary, this study demonstrates how monetary policy changes flow through the banking sector, and that different types of loans may react to monetary shock differently. It also shows that factors associated with changes of loans vary with the lenders as well as with types of loans. Policy makers may need to bear this in mind when making decisions on monetary policy, and a coordination of regulatory and macroeconomic policies considering both bank size and the loan industry may offer better monetary control of bank loan growth or decline and the effect on real economic activity.

\section{References}

Agresti, A 2002 Categorical Data Analysis, John Wiley and Sons, New York. http://dx.doi.org/10.1002/0471249688

Altunbas, Y, Fazylov, O \& Molyneux, P 2002, 'Evidence on the Bank Lending Channel in Europe', Journal of Banking \& Finance, vol.26, no. 11, pp2093-2110. http://dx.doi.org/10.1016/S0378-4266(02)00201-7

Amemiya, T \& MaCurdy, TE 1986, 'Instrumental-Variable Estimation of an ErrorComponents Model', Econometrica, vol.54, no. 4, pp869-880.

Ashcraft, AB 2006, 'New Evidence on the Lending Channel', Journal of Money, Credit \& Banking (Ohio State University Press), vol.38, no. 3, pp751-775. http://dx.doi.org/10.1353/mcb.2006.0037

Becketti, S \& Morris, C 1992, 'Are bank loans still special?', Economic Review - Federal Reserve Bank of Kansas City, vol.77, no. 3, pp71-83.

Berger, AN 2003, 'The economic effects of technological progress: Evidence from the banking industry', Journal of Money, Credit \& Banking (Ohio State University Press), vol.35, no. 2, pp141-176. http://dx.doi.org/10.1353/mcb.2003.0009

Berger, NA \& Udell, FG 1998, 'The economics of small business finance: The roles of private equity and debt markets in the financial growth cycle', Journal of Banking \&amp; Finance, vol.22, no.6-8, pp613-673

Bernanke, BS \& Blinder, AS 1992, 'The federal funds rate and the channels of monetary transmission', The American Economic Review, vol.82, no. 4, pp901-921.

Buigut, S 2010, 'Is there a Bank Lending Channel of monetary policy in Kenya?', International Research Journal of Finance and Economics, no. 45, pp182-191.

Ehrmann, M, Gambacorta, L, Pagés, JM, Sevestre, P \& Worms, A 2003, 'The effects of monetary policy in the Euro area', Oxford Review of Economic Policy vol.19, no.1, pp58-72. http://dx.doi.org/10.1093/oxrep/19.1.58

Hausman, JA \& Taylor, WE 1981, 'Panel data and unobservable individual effects', Econometrica, vol.49, no. 6, pp1377-1398. http://dx.doi.org/10.2307/1911406

Kakes, J \& Sturm, J-E 2002. 'Monetary policy and bank lending: Evidence from German banking groups', Journal of Banking \& Finance, vol.26, no.11, pp2077-2092. http://dx.doi.org/10.1016/S0378-4266(02)00200-5 
Kashyap, AK \& Stein, JC 1995, 'The impact of monetary policy on bank balance sheets', Carnegie-Rochester Conference Series on Public Policy, vol.42, no.1, pp151-195. http://dx.doi.org/10.1016/0167-2231(95)00032-U

Kashyap, AK \& Stein, JC 1997, 'The role of banks in monetary policy: A survey with implications for the European Monetary Union', Economic Perspectives: Federal Reserve Bank of Chicago, pp2-18.

Kashyap, AK \& Stein, JC 2000, 'What do a million observations on banks say about the transmission of monetary policy?', The American Economic Review vol.90, no.3, pp407-428. http://dx.doi.org/10.1257/aer.90.3.407

Kishan, RP \&, Opiela, TP 2000, 'Bank size, bank capital, and the Bank Lending Channel', Journal of Money, Credit and Banking, vol.32, no.1, pp121-141. http://dx.doi.org/10.2307/2601095

Matousek R \& Sarantis, N 2009., 'The Bank Lending Channel and monetary transmission in Central and Eastern European Countries', Journal of Comparative Economics, vol.37, no.2, pp321-334. http://dx.doi.org/10.1016/j.jce.2008.09.008

Ramlogan, C 2004, 'The transmission mechanism of monetary policy: Evidence from the Caribbean', Journal of Economic Studies, vol.31, no. 5, pp435-447. http://dx.doi.org/10.1108/01443580410555537

Suzuki, T 2004, 'Is the lending channel of monetary policy dominant in Australia?', Economic Record, vol.80, no. 249, pp145-156. http://dx.doi.org/10.1111/j.14754932.2004.00169.x

The Australian Prudential Regulation Authority 2011, 'Monthly Banking Statistics', accessed 20/072011,http://www.apra.gov.au/adi/Publications/Pages/monthly-bankingstatistics.aspx

The Reserve Bank of Australia 2011a, 'About Monetary Policy'. accessed 20/07/2011, http://www.rba.gov.au/monetary-policy/about.html

The Reserve Bank of Australia 2011b, Monetary Policy Changes, accessed 20/072011, http://www.rba.gov.au/statistics/tables/index.html\#rba

The Reserve Bank of Australia 2011c, Indicators of Spending and Confidence, accessed 20/07/2011, http://www.rba.gov.au/statistics/tables/\#output_labour 